This item is the archived peer-reviewed author-version of:

Transnational social work : challenging and crossing borders and boundaries

\title{
Reference:
}

Schrooten Mieke.- Transnational social w ork : challenging and crossing borders and boundaries

Journal of social w ork - ISSN 1468-0173 - Thousand oaks, Sage publications inc, 2020, , 1468017320949389

Full text (Publisher's DOI): https://doi.org/10.1177/1468017320949389

To cite this reference: https://hdl.handle.net/10067/1708610151162165141 


\section{Transnational social work: Challenging and crossing borders and boundaries}

\section{Introduction}

In the summer of 2019, artists and architects installed three temporary pink seesaws in between the metal slats of an older section of border wall that runs between El Paso in Texas and Ciudad Juárez in Mexico. The seesaws were designed by architectural studio Rael San Fratello, in cooperation with Taller Herrería, a workshop located in Ciudad Juárez. Ronald Rael, an architecture professor at the University of California, Berkeley, and Virginia San Fratello, an associate professor of design at San José State University, began investigating the US-Mexico border in 2000. About 10 years ago, they came up with the seesaw concept as the 'Teeter Totter Wall' (Rael, 2017). Rael San Fratello's seesaws installation followed a string of controversies surrounding the American president Trump's commitment that a wall would be built between the United States and Mexico, in addition to border barriers constructed during the administrations of Barack Obama and George W. Bush. Even though the installation only remained there for a couple of hours, the images and videos of the children on both sides of the border playing together spread quickly on social media. The project also attracted considerable media attention throughout the world.

The seesaws are but one of the many examples in which borders initiate a firestorm of international debate. Over the last decades, borders - and wanted or unwanted border-crossings of people, ideas and goods - have been at the centre of global attention. Amongst policy makers, media, as well as academics, debates on the function and the management of borders have expanded considerably 
(Bachelet \& Richard, 2018; Clarke et al., 2017; Georgiou \& Zaborowski, 2017). This is not surprising, as - as the example of the U.S.-Mexico border demonstrates - borders still have a strong impact on everyday life. At the same time, numerous social processes and structures are intertwined across borders (Negi \& Furman, 2010). Many of the current concerns of the profession of social work - such as social inequality, ecology or human mobility - go beyond the particularity of nationstates and have an explicit transnational dimension. What's more, a growing number of people lead 'transnational lives', i.e. lives that transcend national borders (Faist et al., 2013; Vertovec, 2009).

Altogether, borders and cross-border processes and structures pose essential challenges for social work as, on the one hand, they affect the everyday life worlds of community members, service users and professionals, as well as social work organisations and political frameworks. On the other hand, they question fundamental concepts and assumptions and, as Hunter et al. (2010, p. 222) argue, ask for a paradigm shift, as "social workers can no longer pay attention to relationships, resources, structures, laws and history in one locale and not consider the same in another country where the systems may be informed by a significantly different world view for their clients." An exclusive 'local' and 'sedentary' (Malkki, 1992) focus would be contrary to several clients' mobile and/or transnational life and/or to the border-crossing nature of the themes social workers encounter (Boccagni, 2015; Withaeckx et al., 2017). This paper gives an overview of the way this transnational perspective has been developed within social work and aims to set a research agenda for a transnational social work that recognises and explores, as well as challenges and crosses borders and boundaries.

\section{Borders and 'the transnational' as prominent topics of research}


Whereas the pioneering framework for border studies can be traced back to the end of the $19^{\text {th }}$ century (Laine, 2015), the current scientific attention to borders can partially be attributed to the emergence of counter-narratives to globalisation discourses of the late 1980s and early 1990s (Kolossov \& Scott, 2013). For a rather short but influential period, discourses of globalisation and cosmopolitanism highlighted and celebrated global 'flows' of people, objects and ideas. Most early globalisation scholars argued that globalisation pressured on state borders to the extent that borders were opening and, in some cases, a 'borderless world' was emerging (debordering) (Appadurai, 1996; Horsman \& Marshall, 1994; O’Brien, 1992; Ohmae, 1990). The weakening influence of states in face of mega-corporations were seen as exemplary in this case. In the same period, social anthropologists Glick Schiller, Basch and Szanton-Blanc (1992) launched the concept of 'transnationality' to identify how migrants maintain family, economic, social, organisational, religious and political relationships across borders: migrants take decisions, show interest and negotiate identities with the social networks that connect them with at least two countries (Portes et al., 1999). Therefore, transnational migration would lead to a globalisation 'from below' (Portes, 2003), creating communities that sit astride political borders and that, in a very real sense, are 'neither here nor there' but in more than one national state simultaneously.

In academia, there has been an explosion of relevant literature on transnationality and borders, including books and a growing number of regional and international journals in the field. Several research centres explicitly focus on borders and/or transnationality and the topics are dealt with in many educational programs in different disciplines throughout the world. Whereas the literature on transnationality is still strongly influential in current academia - even though 'translocality' is put forward as an alternative term (Greiner \& Sakdapolrak, 2013) -, the perspective of a 'borderless world' has been contested on two levels. On the one hand, from a geographical perspective, 
contemporary scholars in the field of border studies argue that state borders retain their significance, albeit under new appearances. They may be opening to certain cyber, social and economic functions, but are at the same time (re-)closing to other security and political functions (rebordering) (Newman, 2006; Popescu, 2011; Salazar \& Smart, 2011), even more so in the post 9/11 era (Bigo, 2002; Goldin et al., 2012; Hyndman \& Mountz, 2007; Padilla, 2011). A clear-cut example is the instauration of stringent laws on the border controls which, according to the USA, EU and other governments, were originally designed to stop terrorists, but that are being applied to various kinds of mobile people, including migrants (Adey, 2004; Schrooten, Salazar, \& Dias, 2016).

On the other hand, more anthropologically inspired border research emphasises the strengthening of metaphorical and symbolic boundaries such as class, religion, length of residence at a certain location, gender, race, ethnicity and nationality, linking the concept of boundaries to a much broader intellectual agenda critiquing modernist conceptions of space and time (Alvarez, 1995; Anzaldúa, 1987; Elias \& Scotson, 1965; Pratt, 1991). Although literature on symbolic boundaries is proliferating across a wide range of topics and disciplines (see Lamont et al., 2015), it has been particularly influential in anthropology, cultural sociology and ethnic and racial studies (Alba, 2005; Barth, 1969; Brettell, 2008; Hazir, 2014; Karlsen \& Nazroo, 2015; Lacy, 2007; Saperstein \& Penner, 2012; Schrooten, 2012; Wimmer, 2008). Research within this field has focused on how people draw symbolic boundaries to construct their own identity and the ways they position themselves and others in multiple and changing social groups. Symbolic boundaries may lead to processes of othering, in which a strong focus is placed on distinctions between 'us' and 'them', and to practices of exclusion (Ecklund, 2005; Sibley, 1995). Moreover, symbolic boundaries can have an impact on what are often called 'social boundaries', "objectified forms of social differences 
manifested in unequal access to and unequal distribution of resources (material and nonmaterial) and social opportunities..." (Lamont \& Molnár, 2002, p. 168), which link them directly to the agenda of social work.

Despite the relevance of boundaries, borders and border-crossing developments for social work, social work is just at its beginnings in systematically reflecting and analysing their significance (Furman et al., 2010; Righard \& Boccagni, 2015; Schrooten, Geldof, \& Withaeckx, 2016). Highly significant in this matter is the 'methodological nationalism' (Wimmer \& Glick Schiller, 2003) at work in the theory and practice of social work, meaning that the nation-state remains firmly embedded in social work concepts, policies and practices as a naturalised and unquestioned frame of reference. Problem definitions, categories of analysis and methods of social work are still mostly situated within the context of the nation-state and its organisations and institutions, falling short in examining transnational processes and welfare institutions (Kettunen \& Petersen, 2011). It is relevant to mention, in this respect, the processes of nation building and nationalism brought forth by the nineteenth and twentieth centuries (Pries, 2005). In this period, nation-bounded thinking was the predominant way of perceiving social order and positioning social structures and social change, which provides some reasons why most people work within (imagined) national boundaries and become faithful to national policies and practices (see Anderson, 1983; Gellner 1983).

The history of formalised social work also plays an important role in this methodological nationalism. Western formal social work emerged in the late 19th century, in the context of the development of industrialised economies (Payne, 2005). In most Western countries, social work is organised public welfare provision, meaning that organisations offering welfare services are mainly funded by the state. Besides the funding, the relevant legislation and the structures for cooperation 
are also mainly organised at a (sub)national level. I argue, however, that developing a perspective beyond the state as a national container of all processes is vital for 21 st century social work. Accordingly, this paper sets out to move away from the methodological nationalism within social work, embracing the transnational turn away from sedentary and local conceptualisations of a society bounded by national borders.

\section{Social work as a border-crossing profession}

Despite the fact that the state is still one of the crucial frameworks organising the social work profession, social work has, in many ways, always been transnationally entangled. Even the founders of formalised social work in Europe were already involved in international exchange of ideas (Kendall, 2000). In 1928, the First International Conference of Social Work took place in Paris, drawing 2500 participants from forty-two countries. Out of these meetings emerged the three best known and longest established international bodies in social work, namely the International Association of Schools of Social Work (IASSW), the International Federation of Social Workers (IFSW) and the International Council on Social Welfare (ICSW) (Healy, 2012). In addition, several less formal and more fluid transnational academic and practice networks have periodically been significant in sharing and developing knowledge.

One of the most visible aspects of the international dimension of social work has been the formulation of an international definition of social work. Even though the literature often refers to the definition of 1982 as the 'first' international definition, the IFSW points to an earlier precedent. Already in 1957, two study groups with representatives of nine European countries (Belgium, Denmark, France, Germany, Italy, Scotland, Sweden and Switzerland) developed what is believed 
to be the first international definition of social work. Their report was published in 1959 and proposed the following definition of social work:

Social work is a systematic way of helping individuals and groups towards better adaptation to society. The social worker will work together with clients to develop their inner resources and he will mobilize, if necessary, outside facilities for assistance to bring about changes in the environment. Thus, social work tries to contribute towards greater harmony in society. As in other professions, social work is based on specialized knowledge, certain principles and skills (IFSW, 1959, p. 3).

The international context of this report was limited to Europe. It was only at the end of the 1970s that efforts were made to create a broader international definition, which was endorsed at the Brighton conference in 1982 by representatives from 44 countries. The 1982 definition read as follows:

Social work is a profession whose purpose it is to bring about social changes in society in general and in its individuals forms of development (Hall, 2009).

This definition remained unaltered until 1996 when a committee was established to revise and prepare a new definition of social work, ultimately adopted by both practitioners and educators in 2001. The major global changes that had occurred since 1982 - in the world as well as in social work itself - served as the backdrop to this initiative (Hare, 2004). As such, the definition aimed to take this international context of social work into account. The core definition was the following: 
The social work profession promotes social change, problem solving in human relationships and the empowerment and liberation of people to enhance well-being. Utilising theories of human behaviour and social systems, social work intervenes at the points where people interact with their environments. Principles of human rights and social justice are fundamental to social work (International Federation of Social Workers, 2000).

Since its adoption, however, the definition of June 2001 has come under considerable criticism. Critics centred on the perceived Western bias, with its emphasis on individual rights, and the lack of recognition of collective rights. Moreover, a major concern to indigenous social workers has been that the definition made no reference to indigenous knowledge. As a response to this criticism, the IFSW and the IASSW jointly engaged in a process to review the 2001 definition. In July 2014, they formulated a new global definition of the social work profession, that is still in use today:

Social work is a practice-based profession and an academic discipline that promotes social change and development, social cohesion, and the empowerment and liberation of people. Principles of social justice, human rights, collective responsibility and respect for diversities are central to social work. Underpinned by theories of social work, social sciences, humanities and indigenous knowledges, social work engages people and structures to address life challenges and enhance wellbeing.

The above definition may be amplified at national and/or regional levels (IASSW General Assembly \& IFSW General Meeting, 2014)

\section{From international to transnational social work}


During some periods and in some places in the world, the international orientation of social work has been forgotten or neglected. Beginning in the last years of the twentieth century, however, there has been a growing interest in the international aspects of social work and the impact of the 'global' on its local workings (Healy, 2012; Payne \& Askeland, 2016; Ramanathan \& Link, 1999). During the last decades, issues related to globalisation, internationalisation and transnationality have started to receive more attention among social work scholars. Reflections on the changing nature of social work against the backdrop of globalisation have given rise to new conceptualisations of social work, reflected in the development of the notions of international and transnational social work. Both concepts aim to capture the necessary changes involved in exercising social work in a context of globalisation and mobility, albeit with a different focus.

Although the term 'international social work' had been used in the 1920s already, scholarship on the topic has intensified only in the early twenty-first century. The concept of international social work has examined the national limitations of social work by recognizing and emphasising that actors, policies, and social services do not stop at state borders (Cox \& Pawar, 2006; Healy, 2008; Midgley, 2001). While the literature on international social work is very extensive by now, it does not offer any unitary definition of the concept. Proposed definitions range from very broad including all aspects of the profession that involve more than one country (Sanders \& Pedersen, 1984) - to very narrow (Stein, 1957), from general (Boehm, 1976) to specific (Lyons, 1999), and from functional (Healy, 2008; Hugman et al., 2010) to value based (Ahmadi, 2003; Payne \& Askeland, 2016).

Hugman et al. (2010) identify five elements that may be considered as indicative of international social work: (1) the practice of social work in a country other than the home country of the social 
worker; (2) working with communities that originate in another country (immigrants, refugees, et cetera); (3) working with international organisations; (4) exchanges or collaborations between countries; and (5) the incorporation of the notion of globalisation, implying an understanding of the local context in terms of the impact of economic and cultural globalisation on the local sociocultural domain, as well as the impact of the local on the global.

The relatively new concept of co-creation of knowledge via international social work has been subject to similar critics as the 2001 international definition of social work (Lavalette \& Ioakimidis, 2009; McInnes, 2013; Moosa-Mitha \& Ross-Sheriff, 2010; Yip, 2004). Payne and Askeland (2016) argue that it is no more than Western social work influencing the rest of the world through postcolonial cultural hegemony. Scholars of international social work have tended to universalise from their epistemological and experiential bases to 'teach' those in the South how to understand and do social work (Lyons, 2006). Social work values, norms, and practices are thus affected by specific understandings of 'the good' (Hugman, 2012), which are not necessarily shared within non-Western communities and localities. Nevertheless, values assumed to be universal have for a long time informed dominant understanding of social work and have thus participated in the denigration and eclipse of non-Western understandings of justice and social work (Green \& Baldry, 2008).

Another line of critique on international social work is that it "does not acknowledge the glocal nature of social reality, including a critique of the practices of welfare states in the North and their participation in equitable processes of globalization" (Moosa-Mitha \& Ross-Sheriff, 2010, p. 106). Similarly, Haug (2005) states that international social work lacks a critical analysis and attention to global power relations, specifically relating to the historical and contemporary dynamics of 
imperialism, colonisation and Western hegemony in the 'new world order' sculpted by neoliberalism.

The concept of 'transnational social work' seems to open a different and more innovative conceptual space for border-crossing social work. Furman, Negi and Salvador (2010, p. 8), who used the notion first, conceptualise it as follows:

Transnational social work is an emerging field of practice that (a) is designed to serve transnational populations; (b) operates across nation-state boundaries whether physically or through new technologies; and (c) is informed by and addresses complex transnational problems and dilemmas.

Hence, transnational social work is "a practice that can deftly move across nation-state boundaries, be culturally competent and responsive on a local level, yet recognise the continued strength and centrality of nations" (Furman et al., 2010, p. 4).

Transnational social work typically criticises social work for its restricted focus on a geographically defined space and regards instead social work across state borders and cultural boundaries. A central element is the focus on the border crossings of people, social relations, organisations and policies, and the processes and structures that evolve when these social flows transcend national borders and connect formerly different social worlds together (Boccagni et al., 2015; Chambon et al., 2012; Olivier-Mensah et al., 2017). This perspective challenges the local and sedentary conceptualisation of society and social life that is still omnipresent today. 
One of the main fields in which social work has reflected more systematically upon border crossing processes is the field of migration (Nobe-Ghelani, 2017; Schrooten, Geldof, \& Withaeckx, 2016). At the same time, transnational social work is by no means limited to these issues. Though the origin of the concept of transnationality can be located within the field of migration research (Glick Schiller et al., 1992), physical mobility is no precondition for a transnationalisation of daily life. It is not only one specific group (such as physical mobile people) that is engaged in border-crossing processes. Rather, transnational studies focus on border-crossing activities and ties of mobile as well as immobile individuals, groups, organisations or movements, thus challenging the traditional understanding of the nation as a closed container (Mau, 2010).

Therefore, transnational social work practice is not limited to social services that work with migrants or that are deliberately designed to be of a transnational nature. It is increasingly the case that social work programs and organisations that are not explicitly geared towards cross-border interrelationships are nevertheless facing transnational challenges (Olivier-Mensah et al., 2017). Likewise, national welfare institutions are becoming increasingly interconnected and influenced by global policy actors and by cross-border processes of policy translation (An et al., 2016; Deacon, 2007).

Much of what has been written around transnational social work so far centres on social work with transnational populations (Furman \& Casey, 2010; Furman \& Negi, 2007; Potocky, 2010; Schrooten, Withaeckx, et al., 2016). Other contributions focus on models and methods for transnational social work (Furman et al., 2008; McNutt, 2010) or investigate the way social workers attempt to deal with global and transnational issues and processes (Boccagni, 2015; Chambon et al., 2012). Another line of research examines the role of cross-border movements of ideas, people 
and resources in shaping welfare institutions (Chambon et al., 2015). Finally, the impact and challenges of the tendency towards 're-bordering' of societies in Europe and North America are also addressed by researchers in the field of transnational social work (Olivier-Mensah et al., 2017). In this sense, transnational social work provides a critical perspective on cultural norms and belonging, in societies as well as within social work practices (see, for example, Nobe-Ghelani (2017) on the reproduction of the logic of neoliberal nationalism and the hegemony of national citizenship by social workers in their daily work). At the same time, the concept of transnational social work is also being conceptualised in other ways than the one mentioned above. Bartley and Beddoe (2018), for example, use it to refer to transnational labour mobility in social work, whereas Walliman (2014) argues that the transnational perspective should be one that cuts across all areas of social work and should be treated as a variable such as gender, for example.

\section{Transnational social work practices}

In order to comprehend and address the current challenges for social work beyond the confines set by methodological nationalism, it is interesting to capture the different responses to border-crossing practices and issues present in the field of social protection. Righard and Boccagni (2015) offer a helpful framework in this regard.

\footnotetext{
*insert figure 1 here*
}

The two-dimensional arrows split up the field of social protection into four ideal types. Fields B and D capture formal social protection on a continuum ranging from completely unilocally to fully translocally anchored. Being translocally anchored may imply, for example, working across boundaries with family members whose involvement with the client may offer insights into his/her 
current situation, or who may offer different types of support that can be useful in the intervention. It can also refer to the involvement in translocal cooperation and networking (Hunter et al., 2010) or to the transformation of a local organisation into a transnational operating structure (Withaeckx et al., 2017). An analysis of different formal social work organisations by degree of transnationality allows to identify different approaches among these organisations to border-crossing practises, clients and issues. Two remarks are important to take into account in this matter. First, as Withaeckx et al. (2017) argue, a translocally anchored social work does not necessarily imply the physical or virtual crossing of national borders. Even at a very local level, social professionals can develop a transnational awareness by understanding and being sensitive towards clients' entanglement in transnational spaces and networks or to border-crossing processes and structures. Second, it is equally important to look at the degree of institutionalisation of transnationality underlying a given intervention. In some cases, transnationally oriented initiatives are pursued on the initiative of an individual social worker or only on an occasional basis, whilst in other cases they correspond to an institutionalised practice (Righard \& Boccagni, 2015; Withaeckx et al., 2017).

Fields A and C (figure 1) capture informal social protection systems as uni- and translocally anchored. Several researchers have emphasised that formal social work only forms one of the many actors involved in the reception and everyday support of people and that informal social protection systems deserve more scientific consideration (Meeus et al., 2019; Phillimore et al., 2019; Schrooten \& Meeus, 2020). Family and neighbourhood networks are examples of unilocal informal social protection systems. Translocal social protection systems refer to economic and social care practices within transnational families, but also within faith-based and other organisations and networks that span state borders (Righard \& Boccagni, 2015). 
Informal settings are of specific relevance when discussing transnational social work practices, as literature reveals a growing importance of many civil society and grass roots organisations in addressing various social needs (Meeus et al., 2019; Schrooten et al., 2017; Schrover \& Vermeulen, 2005). These spaces are "organizational forms that move fluidly between different layers of society without sticking to any one of them" (Enfaltungen, 2001, p. 334) and are essential networks that enable support, learning, connection and mobilisation. Think of churches, spiritual centres, bars, small shops, self-help groups, money-saving groups, sports groups and many more. Although these organisations often thrive under the conceptual and empirical radar of conventional social work research, policy and practice, they reach people that often are not reached by the latter as they are more willing to accept people who are for many different possible reasons excluded from formal assistance or are suspicious towards official services (Schrooten et al., 2019). What's more, many of these networks have an explicit transnational focus and are well aware of the transnational embeddedness of their public (Maskens, 2008; Zibouh, 2019). Unlike most social workers and their organisations, many informal settings are not bounded by an existing national infrastructure of procedures, documents and artefacts that focuses on local and individual support. Therefore, I argue that transnational social work requires a move away from a strict focus on conventional social work practices to include several transnational social work practices, within existing social work settings, but also within 'new', more informal initiatives. The role of these more informal initiatives and their answers to transnational issues and target groups require more scientific attention.

\section{Setting a research agenda for a transnational social work 'on the}

\section{move'}


The discrepancy between the state-boundedness of social work and the transnational dynamics of the social problems it encounters calls for an 'unbounding' of how social work is theorised (Righard, 2018) and a perspective that recognises social work's role beyond a bounded national state. What are then the research prospects ahead for a social work that challenges and crosses borders and boundaries? In the final part of the paper, I add three possible research lines to the focus on informal initiatives that I introduced in the previous section, namely (1) a decolonisation of social work frameworks and practices, (2) empiric research on border-crossing phenomena and processes and their impact on social work, and (3) the development of a conceptual framework that allows to grasp a physical as well as metaphorical conceptualisation of borders.

A first line of research builds on the critiques that have been articulated against the 2001 international definition of social work as well as against international social work. In recent years, we witness increased criticism on conventional social work and related disciplines such as arts, education and research, for reproducing discriminatory societal structures and for their inadequacy to give equal space to ideas, practices and expertise that originate from other bodies of knowledge than the hegemonic Western and white canon (Choate, 2019; Tuhiwai Smith, 1999). This results in homogeneous understandings and normative positions about social work and society, which severely limits the range of possible futures social workers can contribute to (Edensor \& Jayne, 2011; Pieterse, 2011; Robinson, 2006). Moreover, it runs counter to a core principle of the profession, that being social justice (Choate, 2019). Up to now, transnational social work has not explicitly dealt with these issues. A research agenda that builds on these critiques might involve a form of 'decolonisation' of social work frameworks and practices. If we want to come to 'new geographies of theory' for social work (Roy, 2009), bereaved from hierarchy and in which practices are valuated equally, we are pressed to ask to what extent and how we can or need to decolonise 
social work and work towards "a more complex and expansive body of thought" that challenges the existing frameworks and power relations that give shape to the discipline and its institutions (Pieterse, 2011, p. 6). This pushes the discipline to move away from conventional social work practices and from the experience of a limited number of populations as the basis of social work research and practice. It compels us to give space to theories, practices and organisational logics that challenge the way we produce knowledge, give shape to professional relationships and practice our profession.

Secondly, the challenge arises how to capture border-crossing phenomena and processes and their impact on social work practice and research empirically. Central research questions within such a research line can be grouped by the level - micro, meso or macro - of their focus. At the individual level - that of the client and/or the social worker - more knowledge is needed on the needs and concerns of clients with a transnational lifestyle and the impact of border-crossing topics on social work: How to define 'clients' and their 'life environments' against a transnational background? What kind of social problems or needs have an explicit transnational character or are specifically linked to transnational lifestyles or networks? How do physical borders and symbolic boundaries affect the everyday life worlds of community members, service users and professionals? What are people's trajectories to social care? Literature on transnational medical therapy networks has claimed that interconnecting social relationships are not bound to a patient's close surroundings but can possibly embrace vast and wide-ranging transnational networks (Green et al., 2014; Janzen, 2002; Krause, 2008). A similar research approach to social welfare would be promising. From the perspective of the social professional a main challenge is about the skills and competences of social workers. What kind of specific knowledge, attitudes, models, methods or networks do social workers need, in order to be able to pick up social challenges across borders? 
Dealing with border-crossing cases is not only about the individual responses or competences of social workers. The organisational context - the meso level - is as important. A relevant research focus might therefore be about the methodological, organisational and practical implications of a border-crossing social work for social organisations. The challenges for a border-crossing approach to social work, including the internal pressures within and outside of social work are considerable. How can social work surpass the methodological nationalism in which it still is situated? How can social organisations develop border-crossing networks and institutionalise them? What are the organisational implications and how can they support their workers to surpass methodological nationalism? What kind of research methods should we use to capture these issues?

At the macro level, a border-crossing lens applied to social policy analyses demands that the social field is adapted to a context of more transnational challenges. Here the focus should be on the strategies of the social work community to develop structures and policies to work with transnational clients and issues. This implies the development of programmes with a capacity to provide services to people as their psychosocial and physical realities move across national borders (Furman \& Negi, 2007). A true border-crossing focus requests that "scholars re-think a number of social policy concepts traditionally bound to nation-states, such as social rights and citizenship, welfare states and welfare regimes, agency and structure, institutions and discourses" (An et al., 2016, p. 237). This re-thinking can imply a new vision on the welfare state - one that might not stop at national borders - and on citizenship (Trommel, 2017). At the same time, the machinations of domestic funding, public perceptions, domestic political machinations, et cetera, have a bearing on the way in which welfare state re-visioning unfolds. 
This brings us to a last point of discussion. As has been mentioned before, nation-state borders are not the only borders at stake in social work. Besides these physical borders, a variety of more symbolic boundaries - geographic, racial, linguistic, cultural, juridical, institutional and familial, among others - are also of importance for clients as well as social professionals, institutions and the society in general. The development of a conceptual framework that allows to grasp a physical as well as metaphorical conceptualisation of borders could be a strength. At the same time, involving both implies the risk of turning this approach into a catch-all term. A final research line might therefore investigate which conceptual framework could include borders as well as boundaries, without losing its conceptual strength. The research field of border studies might be inspirational in answering this question.

\section{Acknowledgements}

Many thanks to Jan Van den Broeck and Dirk Geldof for their feedback on an earlier version of this paper.

\section{References}

Adey, P. (2004). Secured and sorted mobilities: Examples from the airport. Surveillance \& Society, 1(4), 500-519. https://doi.org/10.24908/ss.v1i4.3333

Ahmadi, N. (2003). Globalization of consciousness and new challenges for international social work. International Journal of Social Welfare, 12(1), 14-23. https://doi.org/10.1111/1468$\underline{2397.00005}$

Alba, R. (2005). Bright vs. blurred boundaries: Second-generation assimilation and exclusion in France, Germany, and the United States. Ethnic and Racial Studies, 28(2), 20-49. 
https://doi.org/10.1080/0141987042000280003

Alvarez, R. R. (1995). The Mexican-US border: The making of an anthropology of borderlands. Annual Review of Anthropology, 24, 447-470. https://www.jstor.org/stable/2155945

An, S., Chambon, A., \& Köngeter, S. (2016). Transnational histories of social work and social welfare - An introduction. Transnational Social Review, 6(3), 236-241. https://doi.org/10.1080/21931674.2016.1222788

Anderson, B. (1983). Imagined communities: Reflections on the origins and spread of nationalism. Verso.

Anzaldúa, G. (1987). Borderlands/ La frontera: The new mestiza. Aunt Lute.

Appadurai, A. (1996). Modernity at large: Cultural dimensions of globalization. University of Minnesota Press.

Bachelet, A., \& Richard, Y. (2018). La construction de la frontière de facto abkhazo-géorgienne, entre enjeux sécuritaires, politiques et identitaires. L'espace Politique, 36(03). https://doi.org/10.4000/espacepolitique.5691

Barth, F. (1969). Ethnic groups and boundaries: The social organization of culture difference. Little, Brown and Company.

Bartley, A., \& Beddoe, L. (2018). Transnational social work: Opportunities and challenges of a global profession. Policy Press.

Bigo, D. (2002). Security and immigration: Toward a critique of the governmentality of unease. Alternatives: Global, Local, Political, 27(1), 63-92. https://doi.org/10.1177\%2F03043754020270S105

Boccagni, P. (2015). Burden, blessing or both? On the mixed role of transnational ties in migrant informal social support. International Sociology, 30(3), 250-268. https://doi.org/10.1177/0268580915570508 
Boccagni, P., Righard, E., \& Bolzman, C. (2015). Mapping transnationalism: Transnational social work with migrants. Transnational Social Review, 5(3), 312-319. https://doi.org/10.1080/21931674.2015.1101243

Boehm, W. (1976). Editorial. International Social Work, 19(3), 1. https://doi.org/10.1177\%2F002087287601900301

Brettell, C. B. (2008). Constructing borders/ crossing boundaries: Race, ethnicity, and immigration. Rowman \& Littlefield Publishers.

Chambon, A., Johnstone, M., \& Köngeter, S. (2015). The circulation of knowledge and practices across national borders in the early twentieth century: A focus on social reform organisations. European Journal of Social Work, 18(4), 495-510.

\section{https://doi.org/10.1080/13691457.2014.953041}

Chambon, A., Schröer, W., \& Schweppe, C. (2012). Transnational social support. Routledge.

Choate, P.W. (2019). The call to decolonise: Social work's challenge for working with indigenous peoples. The British Journal of Social Work, 49(4), 1081-1099. https://doi.org/10.1093/bjsw/bcz011

Clarke, H. D., Goodwin, M., \& Whiteley, P. (2017). Brexit: Why Britain voted to leave the European Union. Cambridge University Press.

Cox, D., \& Pawar, M. S. (2006). International social work: Issues, strategies, and programs. Sage.

Deacon, B. (2007). Global social policy and governance. Sage.

Ecklund, E. H. (2005). 'Us' and 'them': The role of religion in mediating and challenging the 'model minority' and other civic boundaries. Ethnic and Racial Studies, 28(1), 132-150. https://doi.org/10.1080/0141987042000280049

Edensor, T., \& Jayne, M. (2011). Introduction. In T. Edensor \& M. Jayne (Eds.), Mapping the 
margins: Intersectionality, identity politics, and violence against women of color (pp. 1-27). Routledge.

Elias, N., \& Scotson, J. L. (1965). The established and the outsiders. Frank Cass \& Co. Ltd. Enfaltungen, L. (2001). Taxonomy and unfolding. In R. Bunschoten, T. Hoshino, \& H. Binet (Eds.), Urban flotsam: Stirring the city (pp. 265-345). 010 Publishers.

Faist, T., Fauser, M., \& Reisenauer, E. (2013). Transnational migration. Polity Press.

Furman, R., \& Casey, E. (2010). Transnational men. In N. Negi \& R. Furman (Eds.), Transnational social work practice (pp. 143-154). Columbia University Press.

Furman, R., \& Negi, N. J. (2007). Social work practice with transnational Latino populations. International Social Work, 50(1), 107-112. https://doi.org/10.1177/0020872807072500

Furman, R., Negi, N. J., \& Salvador, R. B. (2010). An introduction to transnational social work. In Transnational social work practice (pp. 3-19). Columbia University Press.

Furman, R., Negi, N., Schatz, M. C. S., \& Jones, S. (2008). Transnational social work: Using a wraparound model. Global Networks, 8(4), 496-503. https://doi.org/10.1111/j.1471$\underline{0374.2008 .00236 . x}$

Gellner, E. (1983). Nations and nationalism. Cornell University Press.

Georgiou, M., \& Zaborowski, R. (2017). Media coverage of the 'refugee crisis': A crossEuropean perspective (Council of Europe report DG1(2017)03).

Glick Schiller, N., Basch, L., \& Szanton-Blanc, C. (1992). Towards a transnational perspective on migration: Race, class, ethnicity, and nationalism reconsidered. New York Academy of Sciences.

Goldin, I., Cameron, G., \& Balarajan, M. (2012). Exceptional people: How migration shaped our world and will define our future. Princeton University Press.

Green, G., Davison, C., Bradby, H., Krause, K., Morente Mjias, F., \& Alex, G. (2014). Pathways 
to care: How superdiversity shapes the need for navigational assistance. Sociology of Health \& Illness, 36(8), 1205-1219. https://doi.org/10.1111/1467-9566.12161

Green, S., \& Baldry, E. (2008). Building indigenous Australian social work. Australian Social Work, 61(4), 389-402. https://doi.org/10.1080/03124070802430718

Greiner, C., \& Sakdapolrak, P. (2013). Translocality: Concepts, applications and emerging research perspectives. Geography Compass, 7(5), 373-384. https://doi.org/10.1111/gec3.12048

Hall, N. (2009). News and views... From IFSW. International Social Work, 52(6), 848-851. https://doi.org/10.1177\%2F0020872809348550

Hare, I. (2004). Defining social work for the 21st century: The International Federation of Social Workers' revised definition of social work. International Social Work, 47(3), 407-424. https://doi.org/10.1177/0020872804043973

Haug, E. (2005). Critical reflections on the emerging discourse of international social work. International Social Work, 48(2), 126-135. https://doi.org/10.1177/0020872805050204

Hazir, I. K. (2014). Boundaries of middle-class identities in Turkey. The Sociological Review, 62(4), 675-697. https://doi.org/10.1111\%2F1467-954X.12114

Healy, L. M. (2008). International social work: Professional action in an interdependent world. Oxford University Press.

Healy, L. M. (2012). Defining international social work. In L. M. Healy \& R. J. Link (Eds.), Handbook of international social work: Human rights, development, and the global profession (pp. 9-15). Oxford University Press.

Horsman, M., \& Marshall, A. (1994). After the nation-state: Citizens, tribalism and the new world disorder. HarperCollins.

Hugman, R. (2012). Culture, values and ethics in social work: Embracing diversity. Routledge. 
Hugman, R., Moosa-Mitha, M., \& Moyo, O. (2010). Towards a borderless social work:

Reconsidering notions of international social work. International Social Work, 53(5), 629643. https://doi.org/10.1177/0020872810371203

Hunter, C. A., Lepley, S., \& Nickels, S. (2010). New practice frontiers: Current and future social work with transmigrants. In N. J. Negi \& R. Furman (Eds.), Transnational social work practice (pp. 222-241). Columbia University Press.

Hyndman, J., \& Mountz, A. (2007). Refuge or refusal: The geography of exclusion. In D.

Gregory \& A. R. Pred (Eds.), Violent geographies: Fear, terror, and political violence (pp. 77-92). Routledge.

IASSW General Assembly, \& IFSW General Meeting. (2014, July). Global definition of social work-IASSW-AIETS.org. International Association of Schools of Social Work (IASSW). https://www.iassw-aiets.org/global-definition-of-social-work-review-of-the-global$\underline{\text { definition/ }}$

IFSW. (1959). Report of the international studygroup on the function and working methods of the personnel social worker. https://www.ifsw.org/wp-content/uploads/ifsw$\underline{\text { cdn/assets/ifsw_34833-6.pdf }}$

International Federation of Social Workers. (2000, July). Definition of social work. Adopted by the IFSW General Meeting in Montréal, Canada.

Janzen, J. M. (2002). The social fabric of health: An introduction to medical anthropology. McGraw Hill.

Karlsen, S., \& Nazroo, J. Y. (2015). Ethnic and religious differences in the attitudes of people towards being 'British'. The Sociological Review, 63, 759-781. https://doi.org/10.1111\%2F1467-954X.12313

Kendall, K. A. (2000). Social work education: Its origins in Europe. Council on Social Work 
Education.

Kettunen, P., \& Petersen, K. (2011). Beyond welfare state models: Transnational historical perspectives on social policy. Edward Elgar.

Kolossov, V., \& Scott, J. (2013). Selected conceptual issues in border studies. Belgeo: Revue Belge de Géographie, 1. https://doi.org/10.4000/belgeo.10532

Krause, K. (2008). Transnational therapy networks among Ghanaians in London. Journal of Ethnic and Migration Studies, 34(2), 235-251. https://doi.org/10.1080/13691830701823863

Laine, J. (2015). A historical view on the study of borders. In S. Sevastianov, J. Laine, \& A. Kireev (Eds.), Introduction to Border Studies (pp. 14-32). Dalnauka.

Lacy, K. R. (2007). Blue-chip black. Race, class, and status in the new black middle class. University of California Press.

Lamont, M., \& Molnár, V. (2002). The study of boundaries in the social sciences. Annual Review of Sociology, 28, 167-195.

\section{https://psycnet.apa.org/doi/10.1146/annurev.soc.28.110601.141107}

Lamont, M., Pendergrass, S., \& Pachucki, M. A. (2015). Symbolic boundaries. In J. Wright (Ed.), International encyclopedia of social and behavioral sciences (pp. 850-855). Elsevier.

Lavalette, M., \& Ioakimidis, V. (2009). International social work or social work internationalism? Radical social work in global perspective. In M. Lavalette (Ed.), Radical social work today (pp. 135-152). Policy Press.

Lyons, K. (1999). International social work: Themes and perspectives. Ashgate.

Lyons, K. (2006). Globalization and social work: International and local implications. The British Journal of Social Work, 36(3), 365-380. https://doi.org/10.1093/bjsw/bc1007 
Malkki, L. (1992). National geographic: The rooting of peoples and the territorialization of national identity among scholars and refugees. Cultural Anthropology, 7(1), 24-44. https://www.jstor.org/stable/656519

Maskens, M. (2008). Migration et pentecôtisme à Bruxelles: Expériences croisées. Archives de Sciences Sociales Des Religions, 143, 49-68. https://doi.org/10.4000/assr.16423

Mau, S. (2010). Social transnationalism: Lifeworlds beyond the nation-state. Routledge.

McInnes, A. (2013). Why should they listen to me? Developing social work education and social work in Tajikistan. International Social Work, 56(5), 674-689.

https://doi.org/10.1177/0020872812440716

McNutt, J. G. (2010). Using internet technology for transnational social work practice and education. In N. J. Negi \& R. Furman (Eds.), Transnational social work practice (pp. 184198). Columbia University Press.

Meeus, B., van Heur, B., \& Arnaut, K. (2019). Migration and the infrastructural politics of urban arrival. In B. Meeus, K. Arnaut, \& B. van Heur (Eds.), Arrival infrastructures: Migration and urban social mobilities (pp. 1-32). Palgrave Macmillan.

Midgley, J. (2001). Issues in international social work. Journal of Social Work, 1(1), 21-35. https://doi.org/10.1177\%2F146801730100100103

Moosa-Mitha, M., \& Ross-Sheriff, F. (2010). Transnational social work and lessons learned from transnational feminism. Affilia: Journal of Women and Social Work, 25(2), 105-109. https://doi.org/10.1177\%2F0886109910364366

Negi, N. J., \& Furman, R. (2010). Transnational social work practice. Columbia University Press.

Newman, D. (2006). The lines that continue to separate us: Borders in our 'borderless' world. Progress in Human Geography, 30(2), 143-161. 
https://doi.org/10.1191\%2F0309132506ph599xx

Nobe-Ghelani, C. (2017). Border narratives in Canadian social work: Neoliberal nationalism in the discursive construction of "citizen/Self” and "non-citizen/Other". Transnational Social Review, 7(2), 129-142. https://doi.org/10.1080/21931674.2017.1314656

O’Brien, R. (1992). Global financial integration: The end of geography. Council on Foreign Relations Press.

Ohmae, K. (1990). The borderless world: Power and strategy in the interlinked economy. HarperCollins.

Olivier-Mensah, C., Schröer, W., \& Schweppe, C. (2017). Social work transnationally revisited. Transnational Social Review, 7(2), 123-128.

\section{https://doi.org/10.1080/21931674.2017.1317983}

Padilla, B. (2011). Engagement policies and practices: Expanding the citizenship of the Brazilian diaspora. International Migration, 49(3), 10-29. https://doi.org/10.1111/j.1468-

\section{$\underline{2435.2011 .00694 . x}$}

Payne, M. (2005). The origins of social work. Palgrave Macmillan.

Payne, M., \& Askeland, G. A. (2016). Globalization and international social work: Postmodern change and challenge. Routledge.

Phillimore, J., Bradby, H., Knecht, M., Padilla, B., \& Pemberton, S. (2019). Bricolage as conceptual tool for understanding access to healthcare in superdiverse populations. Social Theory \& Health, 17(2), 231-252. https://doi.org/10.1057/s41285-018-0075-4

Pieterse, E. (2011). Grasping the unknowable: Coming to grips with African urbanisms. Social Dynamics, 37(1), 5-23. https://doi.org/10.1080/02533952.2011.569994

Popescu, G. (2011). Bordering and ordering the twenty-first century: Understanding borders. Rowman \& Littlefield Publishers. 
Portes, A. (2003). Theoretical convergencies and empirical evidence in the study of immigrant transnationalism. International Migration Review, 37(3), 874-892. https://www.jstor.org/stable/30037760

Portes, A., Guarnizo, L. E., \& Landolt, P. (1999). The study of transnationalism: Pitfalls and promise of an emergent research field. Ethnic and Racial Studies, 22(2), 217-237. https://doi.org/10.1080/014198799329468

Potocky, M. (2010). Social work practice with victims of transnational human trafficking. In N. J. Negi \& R. Furman (Eds.), Transnational social work practice (pp. 119-131). Colombia University Press.

Pratt, M. L. (1991). Arts of the contact zone. Profession, 91, 33-40.

Pries, L. (2005). Configurations of geographic and societal spaces: A sociological proposal between 'methodological nationalism' and the 'spaces of flows'. Global Networks, 5(2), 167-190. https://doi.org/10.1111/j.1471-0374.2005.00113.x

Rael, R. (2017). Borderwall as architecture: A manifesto for the U.S.-Mexico boundary. University of California Press.

Ramanathan, C. S., \& Link, R. J. (1999). All our futures: Principles and resources for social work practice in a global era. Brooks/Cole Pub.

Righard, E. (2018). Conceptualizing social work through the lens of transnationalism: Challenges and ways ahead. Nordic Journal of Migration Research, 8(4), 245-253. http://doi.org/10.2478/njmr-2018-0028

Righard, E., \& Boccagni, P. (2015). Mapping the theoretical foundations of the social workMigration nexus. Journal of Immigrant \& Refugee Studies, 13(3), 229-244. https://doi.org/10.1080/15562948.2015.1035473

Robinson, J. (2006). Ordinary cities: Between modernity and development. Routledge. 
Roy, A. (2009). The 21st-century metropolis: New geographies of theory. Regional Studies, 43(6), 819-830. https://doi.org/10.1080/00343400701809665

Salazar, N. B., \& Smart, A. (2011). Introduction: Anthropological takes on (im)mobility. Identities: Global Studies in Culture and Power, 18(6), i-ix. https://doi.org/10.1080/1070289X.2012.683674

Sanders, D. S., \& Pedersen, P. (Eds.). (1984). Education for international social welfare. University of Hawaii and Council on Social Work Education.

Saperstein, A., \& Penner, A. M. (2012). Racial fluidity and inequality in the United States. American Journal of Sociology, 118(3), 676-727. https://www.jstor.org/stable/10.1086/667722

Schrooten, M. (2012). (Trans)Forming boundaries in a contact zone: The experience of Brazilian migrants in Brussels. Revista de Ciencias Sociales, 29, 89-104. http://www.redalyc.org/articulo.oa?id=70824863004

Schrooten, M., Geldof, D., \& Withaeckx, S. (2016). Transmigration and urban social work: Towards a research agenda. European Journal of Social Work, 19(1), 18-30. https://doi.org/10.1080/13691457.2014.1001725

Schrooten, M., \& Meeus, B. (2020). The possible role and position of social work as part of the arrival infrastructure. European Journal of Social Work, 23(3), 414-424. https://doi.org/10.1080/13691457.2019.1688257

Schrooten, M., Salazar, N. B., \& Dias, G. (2016). Living in mobility: Trajectories of Brazilians in Belgium and the UK. Journal of Ethnic and Migration Studies, 42(7), 1199-1215. https://doi.org/10.1080/1369183X.2015.1089160

Schrooten, M., Thys, R., \& Debruyne, P. (Eds.). (2019). Sociaal schaduwwerk. Over informele spelers in het welzijnslandschap. Politeia. 
Schrooten, M., Thys, R., \& Nolf, E. (2017). Zelforganisaties in het Brusselse lokaal sociaal beleid. In P. Raeymaeckers, C. Noël, D. Boost, C. Vermeiren, J. Coene, \& S. Van Dam (Eds.), Tijd voor sociaal beleid. Armoedebestrijding op lokaal niveau (pp. 119-136). Acco.

Schrooten, M., Withaeckx, S., Geldof, D., \& Lavent, M. (2016). Transmigration: Social work in a world of superdiversity. Acco.

Schrover, M., \& Vermeulen, F. (2005). Immigrant organisations. Journal of Ethnic and Migration Studies, 31(5), 823-832. https://doi.org/10.1080/13691830500177792

Sibley, D. (1995). Geographies of exclusion. Society and difference in the West. Routledge.

Stein, H. (1957). An international perspective in the social work curriculum. Annual Program Meeting of the Council on Social Work Education, Los Angeles.

Trommel, W. (2017). Veerkrachtig bestuur: Voorbij neoliberale drift en populistische kramp. Boom Bestuurskunde.

Tuhiwai Smith, L. (1999). Decolonizing methodologies: Research and indigenous people. Zed Books.

Vertovec, S. (2009). Transnationalism. Routledge.

Wallimann, I. (2014). Transnational social work: A new paradigm with perspectives. In C. Noble, H. Strauss, \& B. Littlechild (Eds.), Global social work: Crossing borders, blurring boundaries (pp. 15-26). Sydney University Press.

Wimmer, A. (2008). Elementary strategies of ethnic boundary making. Ethnic and Racial Studies, 31(6), 1025-1055. https://doi.org/10.1080/01419870801905612

Wimmer, A. (2013). Ethnic boundary making. Oxford University Press.

Wimmer, A., \& Glick Schiller, N. (2003). Methodological nationalism, the social sciences, and the study of migration: An essay in historical epistemology1. International Migration Review, 37(3), 576-610. https://doi.org/10.1111/j.1747-7379.2003.tb00151.x 
Withaeckx, S., Schrooten, M., \& Geldof, D. (2017). Thinking and acting globally and locally: Developing transnational social work practices in Belgium. Transnational Social Review, 7(2), 143-157. https://doi.org/10.1080/21931674.2017.1317198

Yip, K.-S. (2004). A Chinese cultural critique of the global qualifying standards for social work education. Social Work Education, 23(5), 597-612. https://doi.org/10.1080/0261547042000252316

Zibouh, F. (2019). Lokale, translokale en transnationale solidariteitspraktijken in het hart van Brussel. In M. Schrooten, R. Thys, \& P. Debruyne (Eds.), Sociaal schaduwwerk. Over informele spelers in het welzijnslandschap (pp. 113-119). Politeia. 